\title{
経験的グリーン関数法に基づく1855年安政江戸地震の 震源パラメーターと地震動の推定 \\ ESTIMATION OF SOURCE PARAMETERS AND STRONG GROUND MOTIONS DURING THE 1855 ANSEI-EDO EARTHQUAKE BY THE EMPIRICAL GREEN'S FUNCTION METHOD
}

\author{
引田智 樹*, 工藤 一 嘉** \\ Tomoki HIKITA and Kazuyoshi KUDO
}

\begin{abstract}
The 1855 Ansei-Edo earthquake caused severe damage to Tokyo(Edo) metropolitan area. The damage was the next to that in the 1923 Kanto earthquake. In this study, source parameters of the 1855 Ansei-Edo earthquake were estimated by obtaining a good match between the simulated strong ground motions by the empirical Green's function method and the macroseismic data (isoseismal map). The hypocenter of the earthquake is most plausible near the border of Chiba and Ibaraki prefectures at a depth of $68 \mathrm{~km}$, near the upper surface of the Pacific plate. The magnitude of 7.4 is the best estimate for interpreting the macroseismic data.
\end{abstract}

Keywords: Ansei-Edo earthquake, isoseismal map, empirical Green's function method, source parameters 安政江戸地震, 震度分布図, 経験的グリーン関数法, 震源パラメーター

\section{1.はじめに}

都市に被害を与える地震がどのようなものであるかを把握するた めに、同地域で発生した過去の被害地震の詳細を知ることは地震対 策の基本である。首都圏地域では、1855 年（安政 2 年）11月 11 日 に発生した安政江戸地震によって東京（当時の江戸）下町を中心に 死者約 1 万人、民家の潰 1 万 4,346 軒の被害が生じた[宇佐美(1996)')]。 この地震による首都圈地域の被害は、1923 年の関東地震に次いで大 きなものである。

宇佐美 $(1996,1995)^{1,2}$ (2)歴史資料の整理から各地の震度を推定し、 その分布からマグニチュード 6.9 、震央位置は北緯 $35.65^{\circ}$ 、東経 $139.8^{\circ}$ と推定している(図 1)。震源深さについては、宇佐美(1976)3) は $40 \mathrm{~km}$ よりも浅い場所で発生したと推定している。また、大竹 $\left.(1980)^{4}\right)$ は、 1894 年明治東京地震や、安政江戸地震を、観測から調 ベた南関東地方の地震メカニズムの分類に当てはめ、安政江戸地震 がフィリピン海プレート上面で発生した地震であることを推察して いる。一方、萩原 5)は、歴史資料の中に P-S 時間が 10 秒程度あっ たと読み取れる記述に注目し、震源深さが $100 \mathrm{~km}$ 程度の可能性を 指摘しており、震源深さについて検討の余地が残されている。

本研究では、実用的な強震動予測手法である経験的グリーン関数 法[Irikura $(1986)^{6}$ ] $]$ により、震源位置と震源規模（マグニチュード） をパラメーターとして地震動を推定し、それによる計測震度分布と、 図 1 に示す宇佐美(1995)2 $)^{2}$ による安政江戸地震の震度分布を比較す る順解析を行うことによって、安政江戸地震の震源位置、マグニチ

$$
\text { ユードについて検討した。 }
$$

同様の研究として、望月,萑本(1986) 7)は、断層モデルを仮定して 理論地震動を計算し、安政江戸地震の震度分布と比較している。し かし、表層の地盤増幅特性により震度分布の形状が特徴付けられる という点に焦点が当てられており、震源位置、震源規模についての 詳細な検討は行われていない。

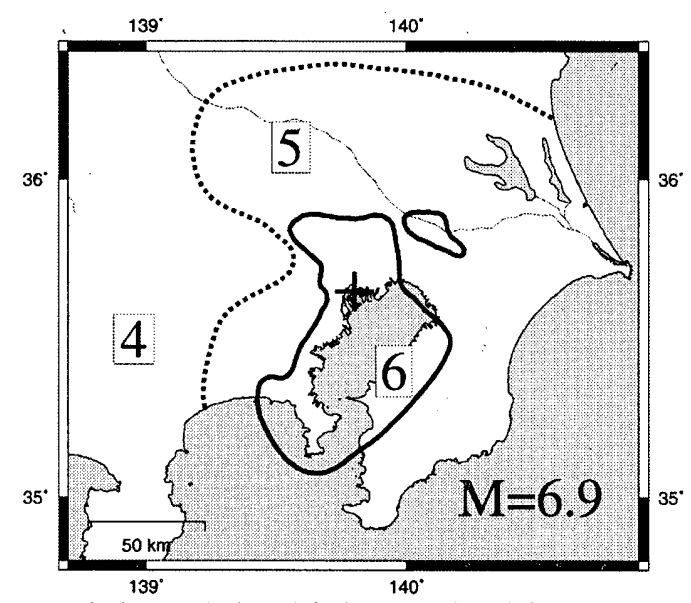

図 1 安政江戸地震の震央位置と震度分布[宇佐美(1995)] 実線、点線が震度 $6 、 5$ の範囲、十が震央を示す。

\section{2. 首都圈地域で発生する地震の相似則}

本研究で用いた Irikura(1986)6)の経験的グリーン関数法は、震源 特性が $\omega^{-2}$ モデル $\left.[\mathrm{Aki}(1967) 8)\right]$ に従い、小地震と大地震の応力降下
* 鹿島建設(侏技術研究所 修士 (工学)

** 東京大学地震研究所 助教授・理博
Kajima Technical Research Institute, M. Eng. Assoc. Prof., Earthquake Research Institute, University of Tokyo, Dr. Sci. 
量が一定の場合の合成式を示している。本章では、対象とする地域 で上記の仮定が成り立つことを確認するため、首都圈地域で発生し た地震の観測記録から、小地震と大地震の震源特性の相似関係を検 討する。

使用した記録は、文部科学省防災科学技術研究所の強震ネット (K-NET(http://www.k-net.bosai.go.jp/))の東京都内の硬質地盤上観 測点(TKY002)で観測された 21 地震に、神奈川県山北町にある東京 大学地震研究所の岩盤上観測点(尺里(HSR))で観測された 5 地震を 加えた合計 24 地震 ( 2 地震は重複) である。使用した地震の震源デ 一夕一覧を表 1 に示す。震央位置はいずれも千葉県から神奈川県西 部に至る首都圏内である。

地表で観測される地震動の $\mathrm{S}$ 波のフーリエスペクトル $O(f)$ は、 次のように表される。

$$
O(f)=x^{-1} S(f) G(f) \exp \left(-\frac{\pi f x}{Q_{s}(f) V_{s}}\right)
$$

ここに、 $S(f)$ は震源スペクトル、 $G(f)$ は観測点近傍の地盤特 性、 $Q_{s}(f)$ は $\mathrm{S}$ 波の $\mathrm{Q}$ 值、 $x$ は震源距離(表1)、 $V_{s}$ は $\mathrm{S}$ 波速度で ある。この式から $O(f), G(f), Q_{s}(f)$ を与えて震源スペクトル $S(f)$ を推定する。このとき、 $V_{s}$ は $3.0 \mathrm{~km} / \mathrm{s} 、 O(f)$ は観測記録の 水平動 2 成分の $\mathrm{S}$ 波到達時から 10 秒間のフーリエスペクトルの二 乗和平方を用い、 $Q_{s}(f)$ は既往の研究[Yoshimoto et al.(1993)9)]か $ら Q_{s}(f)=83.3 f^{0.73}$ とした。また、 $G(f)$ は、TKY002 では K·NET の地下構造データから 1 次元重複反射により求め、HSRについては 良好な岩盤上観測点とみなし、自由表面の影響のみを考え、震源ス ペクトルを抽出した。

求めた震源スペクトルが $\omega \cdot 2$ モデル[Aki(1967)8)]

表 1 相似則の検討に使用した地震の震源デー夕(気象庁による)

\begin{tabular}{|c|c|c|c|c|c|c|c|}
\hline No. & \multirow{2}{*}{ Date } & Lon. & Lat. & $\begin{array}{c}\text { Depth } \\
(\mathrm{km})\end{array}$ & $\mathrm{M}$ & \multicolumn{2}{|c|}{ Hypo. Dist. (km) } \\
\cline { 7 - 9 } & & & & TKY002 & HSR \\
\hline 1 & $1996 / 03 / 06$ & 138.946 & 35.471 & 19 & 4.3 & - & 26.4 \\
\hline 2 & $1996 / 03 / 06$ & 138.951 & 35.473 & 20 & 5.3 & - & 27.0 \\
\hline 3 & $1996 / 07 / 18$ & 138.966 & 35.473 & 20 & 3.5 & 38.2 & - \\
\hline 4 & $1996 / 08 / 09$ & 138.971 & 35.507 & 21 & 4.4 & 35.9 & - \\
\hline 5 & $1996 / 08 / 16$ & 139.851 & 36.129 & 57 & 4.3 & 96.0 & - \\
\hline 6 & $1996 / 10 / 12$ & 139.660 & 36.093 & 91 & 4.7 & 109.5 & - \\
\hline 7 & $1996 / 10 / 25$ & 139.005 & 35.452 & 23 & 4.5 & 40.2 & 26.4 \\
\hline 8 & $1996 / 10 / 25$ & 138.974 & 35.472 & 18 & 4.0 & 36.9 & 24.4 \\
\hline 9 & $1996 / 10 / 26$ & 138.971 & 35.471 & 19 & 3.5 & - & 25.3 \\
\hline 10 & $1996 / 11 / 24$ & 140.108 & 35.751 & 77 & 4.4 & 115.7 & - \\
\hline 11 & $1996 / 12 / 21$ & 139.864 & 36.093 & 53 & 5.4 & 92.7 & - \\
\hline 12 & $1997 / 01 / 14$ & 139.546 & 35.613 & 30 & 3.5 & 48.4 & - \\
\hline 13 & $1997 / 01 / 27$ & 140.079 & 35.752 & 77 & 4.1 & 113.7 & - \\
\hline 14 & $1997 / 06 / 08$ & 139.023 & 35.469 & 13 & 3.6 & 33.3 & - \\
\hline 15 & $1997 / 07 / 09$ & 140.129 & 35.551 & 77 & 4.6 & 118.7 & - \\
\hline 16 & $1997 / 08 / 09$ & 139.505 & 35.829 & 67 & 4.7 & 75.0 & - \\
\hline 17 & $1997 / 09 / 08$ & 140.005 & 35.555 & 109 & 5.2 & 134.6 & - \\
\hline 18 & $1997 / 09 / 24$ & 139.010 & 35.543 & 20 & 3.9 & 31.1 & - \\
\hline 19 & $1997 / 11 / 01$ & 139.118 & 35.250 & 15 & 3.8 & 108.4 & - \\
\hline 20 & $1997 / 11 / 29$ & 139.915 & 36.041 & 50 & 4.3 & 92.0 & - \\
\hline 21 & $1998 / 01 / 14$ & 140.241 & 35.586 & 76 & 4.9 & 125.2 & - \\
\hline 22 & $1998 / 01 / 16$ & 140.307 & 35.205 & 57 & 4.6 & 132.3 & - \\
\hline 23 & $1998 / 07 / 15$ & 139.901 & 36.090 & 51 & 4.4 & 93.8 & - \\
\hline 24 & $1998 / 08 / 29$ & 140.045 & 35.604 & 67 & 5.1 & 105.8 & - \\
\hline
\end{tabular}

$$
S(f)=\frac{M_{0}(2 \pi f)^{2}}{1+\left(f / f_{0}\right)^{2}}
$$

に従うと仮定して、最小二乗近似により地震モーメント $M_{0}$ とコー ナ一周波数 $f_{0}$ を見積った。結果を図 2 に示す。図中の白丸は震源深 さが $30 \mathrm{~km}$ よりも浅い地震から求められた結果を示し、黒丸は 30 $\mathrm{km}$ よりも哚い地震から求められた結果を示す。 $30 \mathrm{~km}$ よりも深い 地震から求められた結果は、地震モーメント $M_{0}$ とコーナー周波数 $f_{0}$ の間に $f_{0} \propto M_{0}^{-2 / 3}$ という応力降下量が一定の場合の相似則[例え ば Aki(1967)8)]に合致する強い相関が見られる（図中の実線、破線 については 6 章で説明する)。この場合、黒丸で示した点に Brune モデル 10)を近似すると応力降下量に比例する実効応力は約 $26 \mathrm{MPa}$ $(260 \mathrm{bar})$ と求められる。一方、30 km よりも浅い地震から求められ た $f_{0}$ と $M_{0}$ の関係は、明らかに $f_{0} \propto M_{0}^{-1 / 3}$ の関係を満たしていない。 しかし、使用した浅い地震はマグニチュードの小さいものが多く、 マグニチュード 7 クラスまでの範囲で相似則を検討するためには規 模の大きな地震のデー夕数が少ない。従って、本研究では $30 \mathrm{~km}$ よ りも深い場所で発生する地震を対象として検討を進め、安政江戸地 震が深い場所で発生した地震である可能性を中心に議論するものと する。

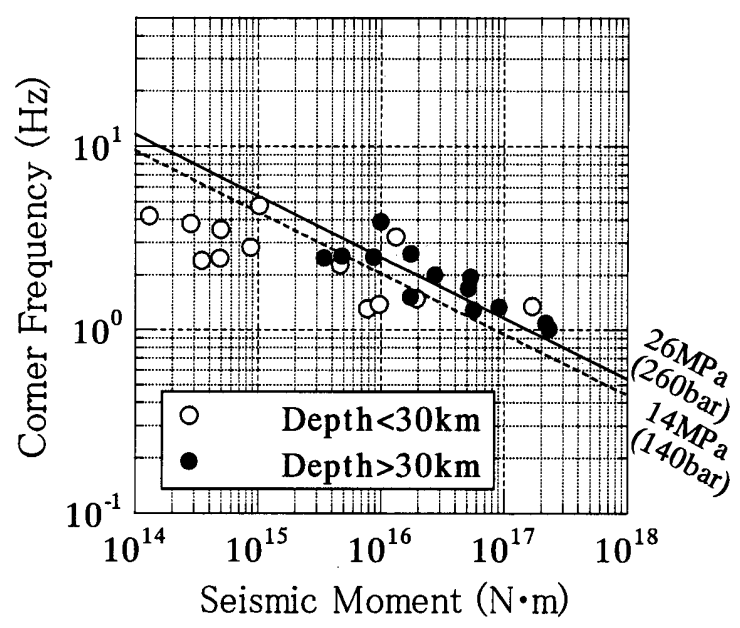

図 2 推定した地震モーメントとコーナー周波数。実線は深 さ $30 \mathrm{~km}$ 以上の地震に対する Brune モデルの近似直線。

\section{3. マグニチュード 6 クラスの地震動の推定}

2 章で求めた相似関係は、マグニチュードが 4.3〜 5.4 までの地震 から求めている。強震動予測を行うためには求めた相似関係が、対 象とする地域において、より地震規模が大きい領域でも満たされる かどうかを確認する必要がある。また、余震・他を用いた波形合成 法の適用例は豊富にあり、手法の有効性はある程度確認されている といえるが、本研究では地震による応力降下量を一定と仮定するこ と、やや哚い地震を対象としていること等、これまでの成果と若干 異なる要素があるため以下の確認を行った。

本研究では計測震度を求め震度分布と比較するため $10 \mathrm{~Hz}$ 程度ま での地震動を評価する必要がある。確認のため本章では、首都圈地 域において観測された小地震記録を合成して、マグニチュード 6 ク ラスの地震の観測記録と比較を行う。なお、地震動を推定する際に、 合成に必要なパラメーター（地震モーメント、断層面積、断層分割 
数、立ち上がり時間）を以下に示す既往の関係式から求めた。

$$
\begin{aligned}
& \log M_{0}=1.5 M_{w}+16.1 \\
& N=\left(\frac{M_{0}}{m_{0}}\right)^{1 / 3} \\
& f_{0}=4.9 \times 10^{6} V_{s}\left(\frac{\Delta \sigma}{M_{0}}\right)^{1 / 3} \\
& r=1.81 \frac{V_{s}}{2 \pi f_{0}} \\
& \tau=\frac{16 S^{1 / 2}}{7 \pi^{3 / 2} V_{s}} \\
& V_{r}=0.72 V_{s}
\end{aligned}
$$

Kanamori (1977)11)

Kanamori and Anderson (1975) ${ }^{12)}$

Brune (1970)10)

Sato and Hirasawa (1973)13)

Geller (1976) 14)

Geller (1976) ${ }^{14)}$

ここで、 $M_{0}$ は地震モーメント $(\mathrm{dyn} \cdot \mathrm{cm}) 、 M_{w}$ はモーメントマグ ニチュード、 $N$ は断層分割数、 $m_{0}$ は要素地震の地震モーメント $($ dyn $\cdot \mathrm{cm}) 、 f_{0}$ はコーナー周波数 $(\mathrm{Hz}) 、 V_{s}$ は $\mathrm{S}$ 波速度 $(\mathrm{km} / \mathrm{s}) 、 \Delta \sigma$ は 実効応力 (bar)、 $r$ は円形断層を考えた場合の半径 $(\mathrm{km}) 、 S$ は断層面 積 $\left(\mathrm{km}^{2}\right)\left(S=\pi r^{2}\right) 、 \tau$ は立ち上がり時間(s)、V は破壊伝播速度 $(\mathrm{km} / \mathrm{s})$ である。なお、気象庁マグニチュード $M_{\mathrm{J}}$ は $M_{w}$ が $5 \sim 7$ 程度 の範囲では系統的に大きな差はないので 15)、以下の議論では $M_{w}$ を $M$, と置き換える。

東京大学地震研究所の江東区猿江(KOT)の観測点で観測された記 録を使用して、1985 年 10 月 4 日に茨城県南部で発生したマグニチ ユード 6.1 の地震の再現を行う。要素地震としたのは、同じ地域で 発生したマグニチュード 4.2 の地震である。要素地震とマグニチュ 一ド 6.1 の地震の震源デー夕を表 2 に、震央と観測点位置図を図 3 に示す。合成のパラメーターのうち走向と傾斜角は堀(1986) ${ }^{16)}$ を参 考にして決定した。パラメーターの一覧を表 3 に示す。断層長 L と 断層幅 $\mathrm{W}$ は、断層面積 $\mathrm{S}$ から $\mathrm{L}=2 \mathrm{~W}$ となるように決めた。合成波 形と観測波形の比較を図 4 に示す。波形は $0.5 \sim 10.0 \mathrm{~Hz}$ のバンドパ スフィルター処理を施した波形である。速度波形と加速度波形とも に観測記録を良く再現している。このとき、観測記録から計算した 計測震度と、合成波形から計算した計測震度はそれぞれ 4.48、4.44

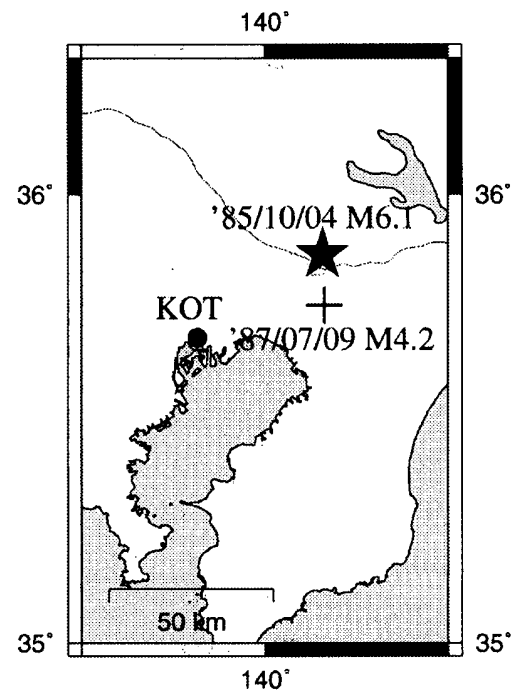

図 3 推定する地震 $(\star)$ と要素地震 $(+)$ 震央および観測点(の)位置
となり両者の差は小さく、計測震度に影響する周期帯で十分な地震 動評価ができていると考えられる。また、2 章で確認した応力降下 量が一定である相似則を用いてマグニチュード 6 クラスの地震動が 十分評価できることから、この相似側が規模の大きい地震に対して も適用できると考えることは妥当であろう。以上から、安政江戸地 震の地震動推定では、上記の相似則がマグニチュード 7 クラスの地 震においても保存されると仮定して検討を進める。

表 2 推定する地震と要素地震の震源デー夕(気象庁による)

\begin{tabular}{|c|c|c|c|c|c|}
\hline & Date & Lon. & Lat. & Depth & $\mathrm{M}$ \\
\hline Target & $1985 / 10 / 04$ & $140.158^{\circ}$ & $35.868^{\circ}$ & $78 \mathrm{~km}$ & 6.1 \\
\hline Element & $1987 / 07 / 09$ & $140.162^{\circ}$ & $37.755^{\circ}$ & $77 \mathrm{~km}$ & 4.2 \\
\hline
\end{tabular}

表 3 合成に使用した震源パラメーター

\begin{tabular}{|c|c|}
\hline 走向 strike & $186.0^{\circ}$ \\
傾斜角 $\mathrm{dip}$ & $45.0^{\circ}$ \\
断層面積 $\mathrm{S}$ & $21.64 \mathrm{~km}^{2}$ \\
断層長 $\mathrm{L}$ & $6.58 \mathrm{~km}$ \\
断層幅 $\mathrm{W}$ & $3.29 \mathrm{~km}$ \\
分割数 $\mathrm{N}$ & 9 \\
立ち上がり時間 $\tau$ & $0.54 \mathrm{~s}$ \\
$\mathrm{~S}$ 波速度 $\mathrm{V}_{\mathrm{S}}$ & $3.5 \mathrm{~km} / \mathrm{s}$ \\
破壊伝播速度 $\mathrm{V}_{\mathrm{r}}$ & $2.5 \mathrm{~km} / \mathrm{s}$ \\
\hline
\end{tabular}
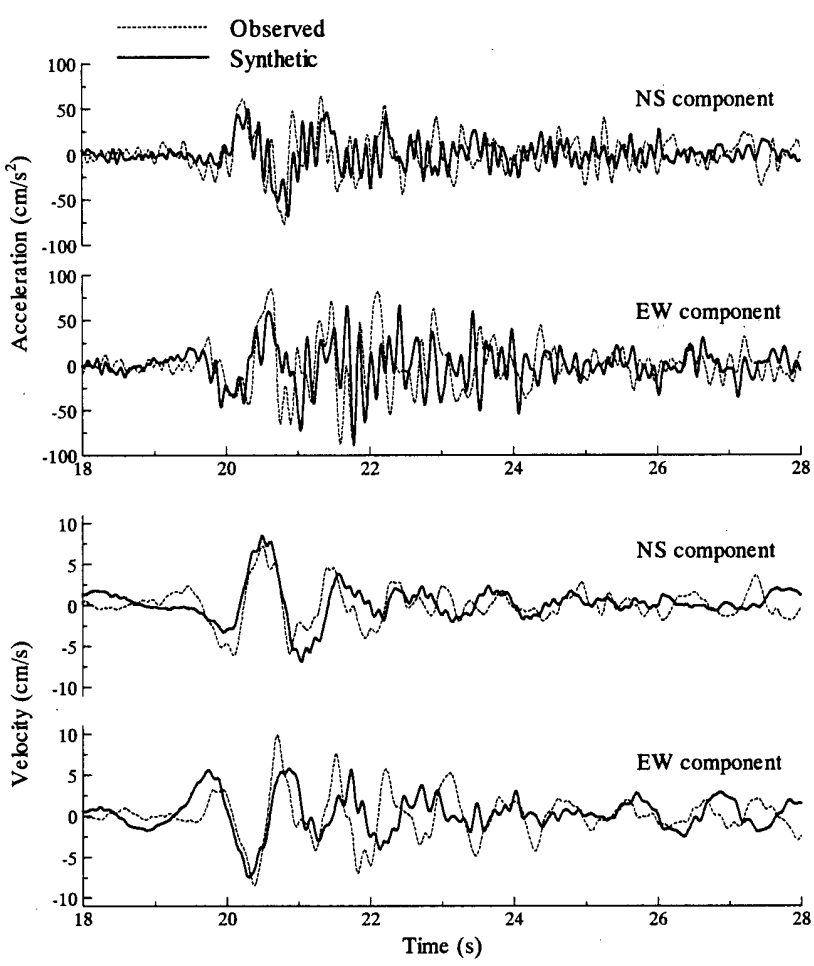

図 4 合成結果と観測記録の波形 $(0.5 \sim 10.0 \mathrm{~Hz})$ の比較

\section{4. 安政江戸地震の震源推定 \\ 4. 1 推定方法}

震源位置、マグニチュードをパラメーターとして変化させて、経 験的グリーン関数法により各地での地震動加速度を計算し、その結 果から気象庁計測震度の算定方法 17 に從い計測震度を求め、気象庁 
震度階級に当てはめた。その時の震度分布が安政江戸地震の震度分 布を最も良く再現する場合の震源パラメーターを推定する、いわゆ るフォワードモデリングを行った。ただし、歴史資料に基づく震度 と計測震度は均質であると仮定して議論を進める。

地震動推定の誤差、安政江戸地震の震度分布の推定誤差、観測点 (震度判定地点)が同一でないこと等を考慮すると、パラメーターの 定量的な評価より、パラメーターによる震度分布の傾向を重視する ベきと考え、パラメーターをある程度絞り込んで検討を行った。

マグニチュードは 7.0 から 0.2 ずつ変化させるものとした。ま た、震央位置については、宇佐美(1996)により推定されている位置 を参考に、安政江戸地震の震度分布において震度が大きい地域を、 マグニチュード 7 クラスのおよその断層面積を考慮して分割した 15 点について検討した。図 5 に検討する候補地点としての震央位置 を示す。図中の実線は図 1 に示した安政江戸地震のおよそ震度 6 以 上の範囲である。

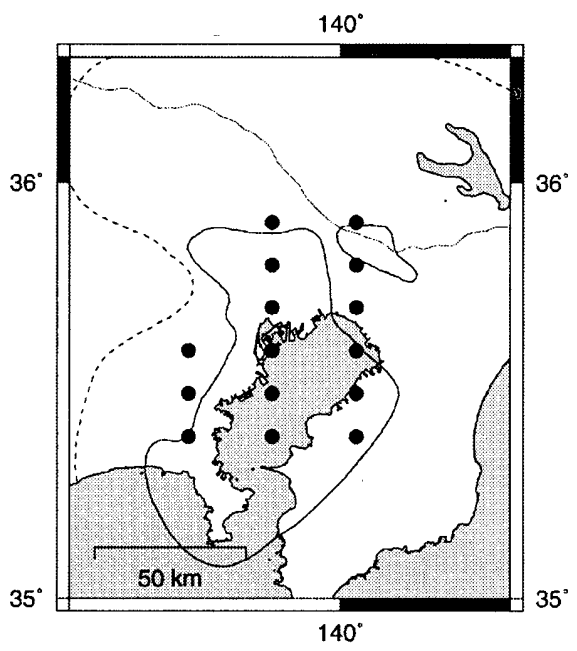

図 5 検討する震央位置(図中の○)

\section{2 要素地震と断層モデルの仮定}

本研究では、震度分布を説明の対象としており、空間的に広い範 囲での比較をする必要があり、そのためには広範囲かつ高密度に配 置された地点で地震動を推定する必要がある。

1998 年 8 月 29 日に東京湾で発生したマグニチュード 5.1 の地震 では、関東地方の K-NET 観測点の 158 観測点で記録が得られ、ま た、東京都の各区、市に配置された震度情報ネットワークのほぼ全 てにあたる 38 観測点で記録が得られた。これは両観測網が展開さ れてから初めてのケースといえる。この地震の震源パラメーターを 表 4 に示す。記録が得られた観測点(K-NET と東京都の観測点) と要 素地震の震央位置を図 6 に示す。多くの観測点で記録が得られてい ることから本研究ではこの地震を要素地震とした。防災科技研によ るメカニズム解では、太平洋プレートの沈み込みの方向に $\mathrm{P}$ 軸を持 つが、ストライクスリップが卓越していることから、この地震はプ レート内地震であると考えられる[堀(1986)16)]。

要素地震の震源媣さは $68 \mathrm{~km}$ であり、太平洋プレートの上面付近 に位置する。メカニズムは、太平洋プレートの视み込みに対応して 存在する二重深発地震面の上面で発生する地震の特徵に似ている。 このことから検討する各震央位置の震源深さは、図 7 に示すように 太平洋プレート上面の深さに沿って、西側ほど深くなるように考え た。想定する断層面は要素地震と同じものを考え、strike $=213^{\circ}$ ， $\operatorname{dip}=66^{\circ}$ とした。なお、破壊開始点は全て断層面の中央として計算 した。

表 4 要素地震の震源デー夕(気象庁による)

\begin{tabular}{|c|c|c|c|c|}
\hline Date & Lon. & Lat. & Depth & M \\
\hline $1998 / 8 / 29$ & $140.046^{\circ}$ & $35.597^{\circ}$ & $68 \mathrm{~km}$ & 5.1 \\
\hline
\end{tabular}

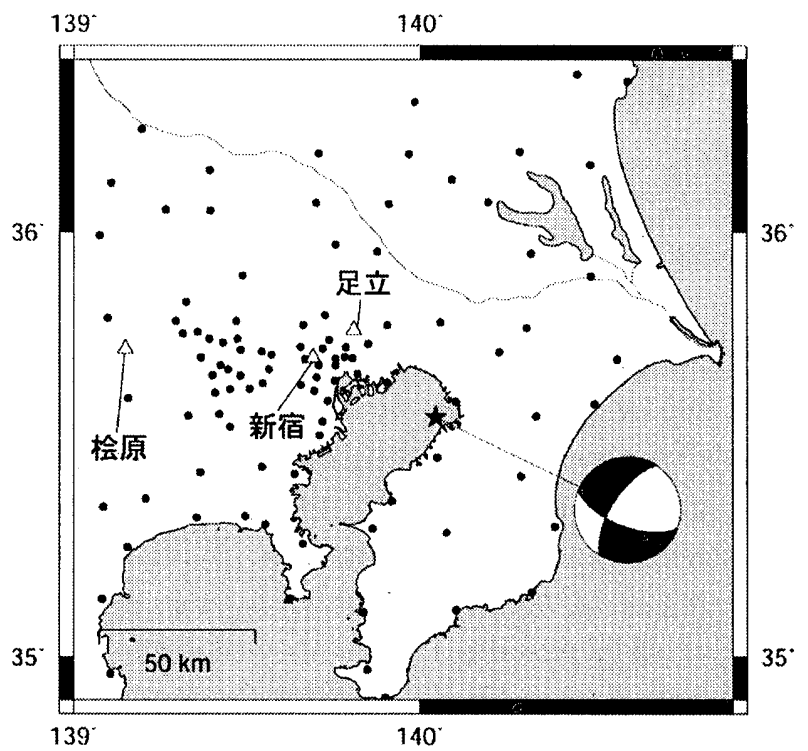

図 6 要素地震の震央位置 $(\star)$ と観測点(○)、およびメカニズム解 (防災科技研,1998 による)

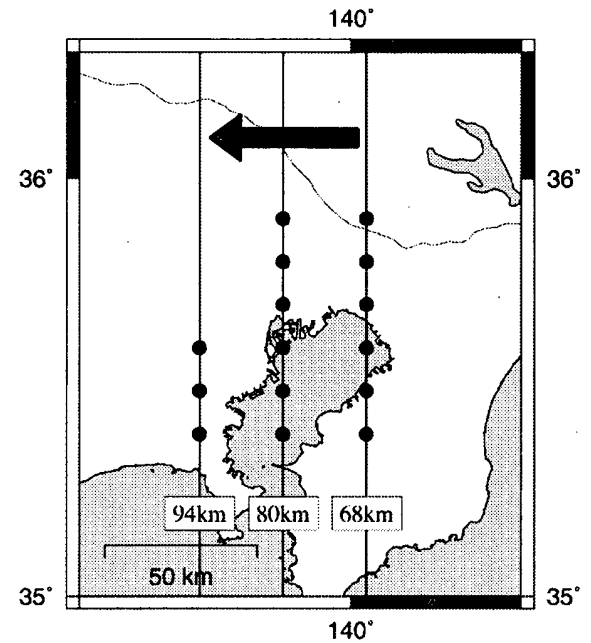

図 7 検討する震源深さ

\section{3 結果}

はじめにマグニチュードを 7.0 に固定して、震源位置を変化させ て計算を行った。結果の一部を図 8 に示す。各観測点の合成波形か ら計算した計測震度を震度階級にして、各記号でプロットする（図 8、図 9 には一部の観測点の結果のみ表示する)。宇佐美(1995)2)によ る安政江戸地震の震度 6 、震度 5 の分布を実線、破線で示す。以降 では比較のため宇佐美(1995)2)による安政江戸地震の震度を「安政江 戸地震の震度」または「震度」と表示し、計算結果である計測震度 
を震度階級にしたものを「計測震度」と表示するが、前述の通り、 震度階の值は均質であると仮定している。

図 8 では、安政江戸地震の震度分布が、千葉県全域を含め埼玉県 や茨城県に至る北側まで震度 5 の範囲が広がるのに対し、計測震度 は全体的にやや過小となる傾向があり、特に計測震度 6 となる地点 が少ない。しかし、震度 5 の範囲の広がりを再現するには、震源位 置を千葉県と茨城県の県境付近に考えた場合（右側）が良いことが わかる。

次に、震源位置を千葉、茨城県境付近に固定してマグニチュード を変化させて計算を行った。結果の一部を図 9 に示す。マグニチュ
一ド 7.2 では埼玉県北部で震度 5 となる部分が再現されない。また、 マグニチュード 7.6 では計測震度 6 の範囲が広くなり過ぎ、マグニ チュード 7.4 を考えた場合 (中央)が最も対応が良いことがわかる。 この場合の、全観測点での結果をまとめて図 10 に示す。結果は安政 江戸地震の震度分布を良く再現している。

以上の検討では、マグニチュードが 7.4、震央位置が千葉、茨城 県境付近、震源深さが $68 \mathrm{~km}$ とした場合に、安政江戸地震の震度分 布の特徵を最も再現する結果（図 10）となった。この時の震源パラ メーターを表 5 に示す。

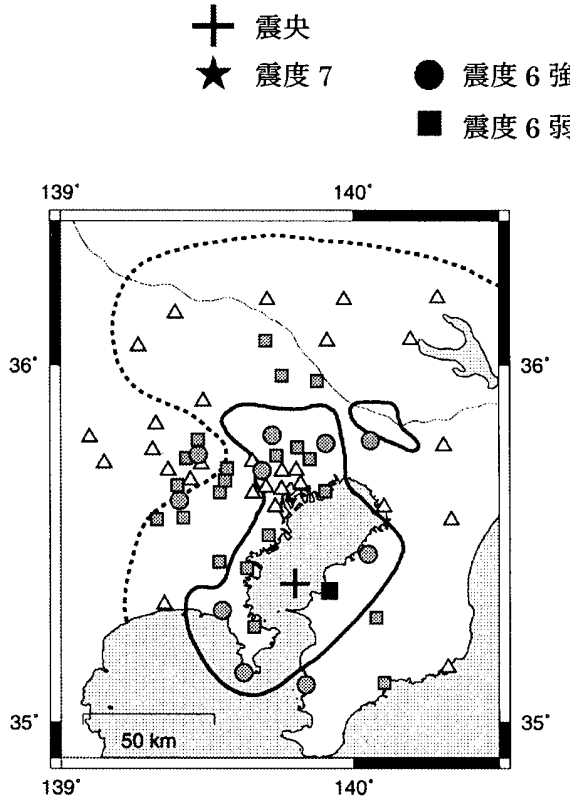

震央位置 $\left(35.39^{\circ} \mathrm{N}, 139.80^{\circ} \mathrm{E}\right)$ 深さ $80 \mathrm{~km}$
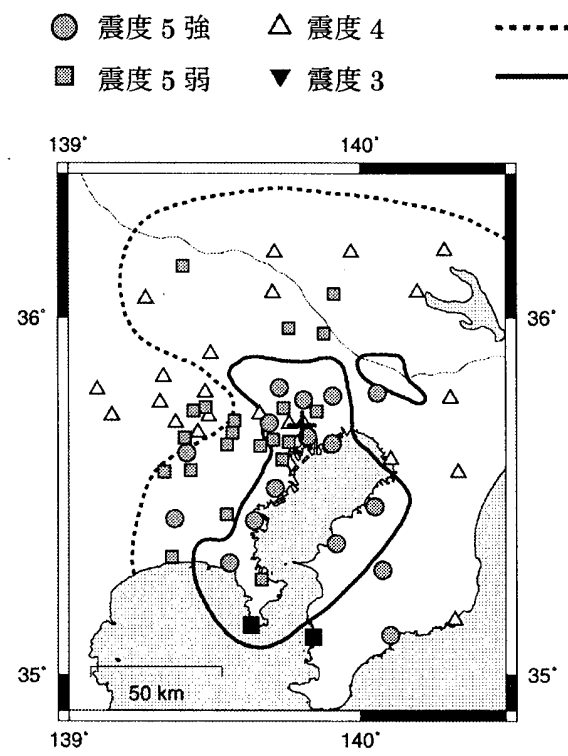

震央位置 $\left(35.70^{\circ} \mathrm{N}, 139.80^{\circ} \mathrm{E}\right)$ 深さ $80 \mathrm{~km}$
安政江戸地震の震度 5 の範囲

安政江戸地震の震度 6 の範囲

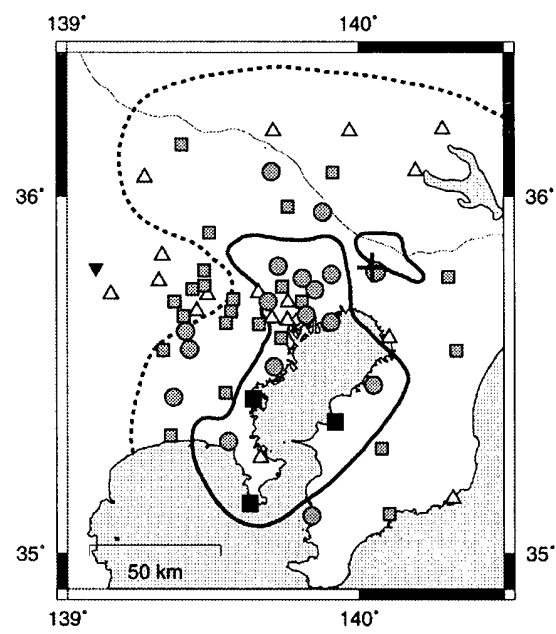

震央位置 $\left(35.80^{\circ} \mathrm{N}, 140.05^{\circ} \mathrm{E}\right)$

深さ $68 \mathrm{~km}$

図 8 震源位置の違いによる震度分布の比較（マグニチュード 7.0）
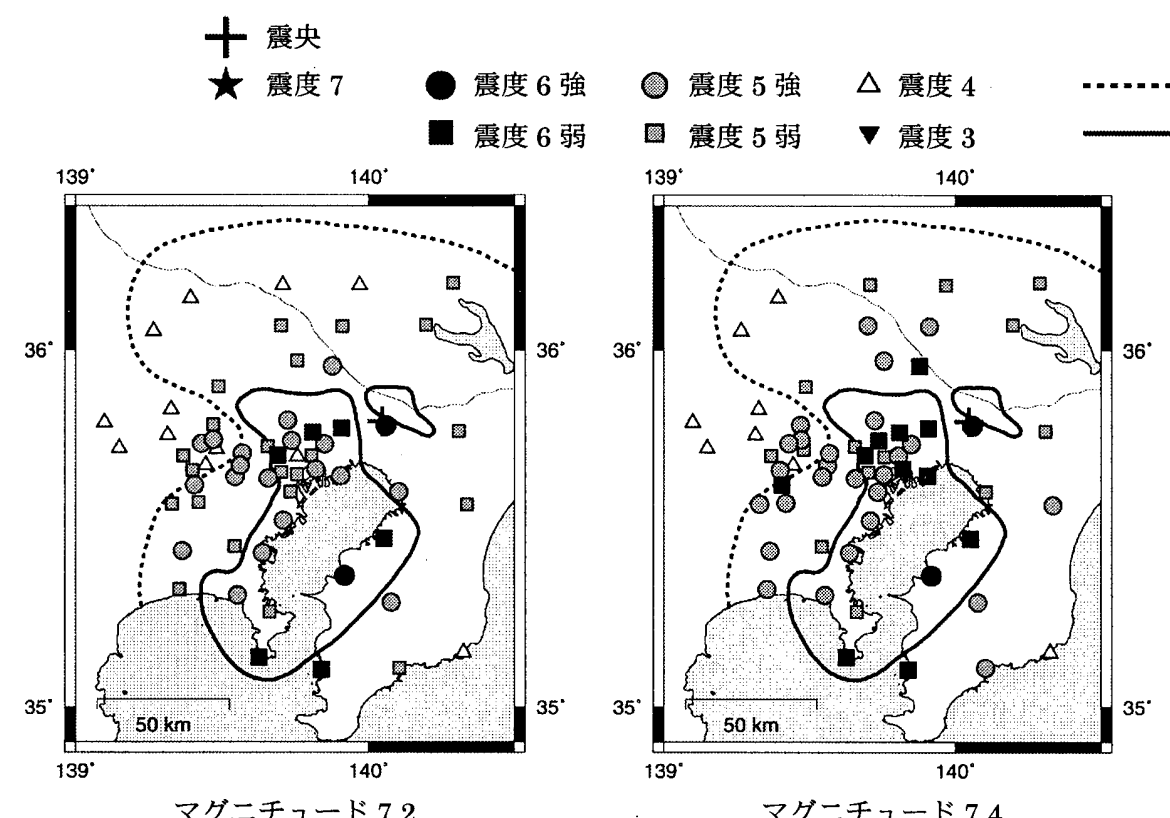

安政江戸地震の震度 5 の範囲

安政江戸地震の震度 6 の範囲

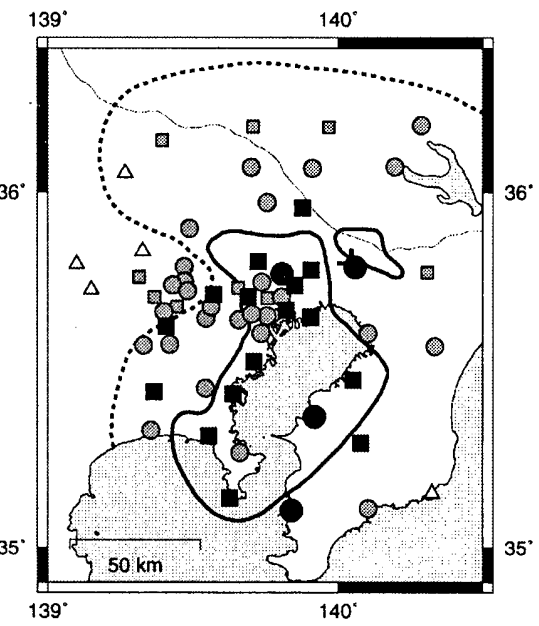

マグニチュード 7.4

マグニチュード 7.6

図 9 マグニチュードの違いによる震度分布の比較（震央位置 $35.80^{\circ} \mathrm{N}, 140.05^{\circ} \mathrm{E}$, 深さ $68 \mathrm{~km}$ ） 


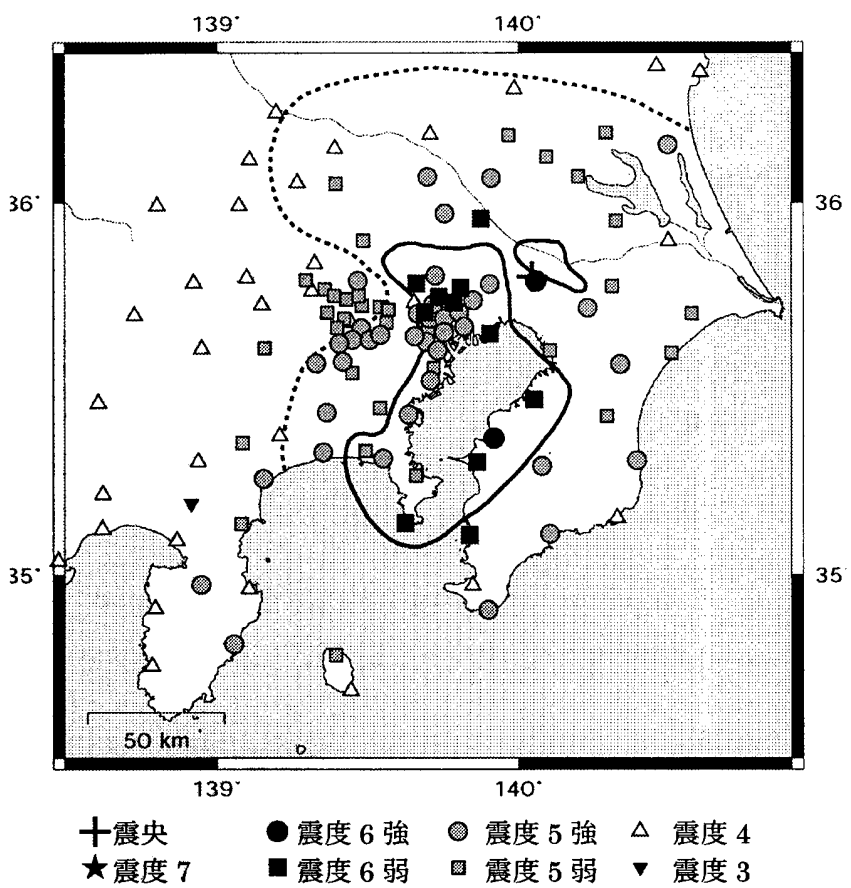

図 10 安政江戸地震の震度分布との比較 (4 章) (マグニチュード 7.4 , 震源哚さ $68 \mathrm{~km}$ )

表 5 結果(図 10)の震源パラメーター

\begin{tabular}{|c|c|}
\hline 走向 strike & $213^{\circ}$ \\
傾斜角 $\mathrm{dip}$ & $66^{\circ}$ \\
断層面積 $\mathrm{S}$ & $344.79 \mathrm{~km}^{2}$ \\
断層長 $\mathrm{L}$ & $26.26 \mathrm{~km}$ \\
断層幅 $\mathrm{W}$ & $13.13 \mathrm{~km}$ \\
分割数 $\mathrm{N}$ & 11 \\
立ち上がり時間 $\tau$ & $1.91 \mathrm{~s}$ \\
$\mathrm{~S}$ 波速度 $\mathrm{V}_{\mathrm{s}}$ & $4.0 \mathrm{~km} / \mathrm{s}$ \\
破壊伝播速度 $\mathrm{V}_{\mathrm{r}}$ & $2.88 \mathrm{~km} / \mathrm{s}$ \\
\hline
\end{tabular}

\section{5. 要素地震を変えた険討}

4 章で推定した計測震度分布は、地震動の推定において、個々の 地震による応力降下量の差異、断層面上での破壊開始位置、破壊の 不均質性などによる影響を考慮に入れていないため、考えられる単 純な想定地震の一つを採用した結果といえる。そこで、これとは別 の、太平洋プレート上面付近で発生する地震を想定し、計測震度分 布を比較する追加検討を行った。 4 章とは別の、表 6 に示す地震を 要素地震として、計測震度分布を算出した。ただし、4 章で求めた 震源パラメーターの中でマグニチュード $(7.4)$ と震源位置 $\left(35.80^{\circ} \mathrm{N}\right.$, $140.05^{\circ} \mathrm{E}$, 深さ $68 \mathrm{~km}$ ）は 4 章と同じとし、推定する地震の断層 走向及び傾斜角は使用する要素地震の断層走向、傾斜角と同じ値と した。つまり、ここで想定する地震は、4 章で推定したものと震源 位置は同じで発震機構が異なる地震といえる。ただし、4 章と同様 に、地震による応力降下量の差異、断層面上の破壊開始位置、破壊 の不均質性などによる影響は考慮しない。求められた計測震度分布 を要素地震の震央位置及びメカニズムと合わせて図 11 に示す。計測 震度分布の形状は要素地震によって当然異なるが、広範囲な分布傾 向を見た場合、計測震度 4 及び 5 の分布はいずれも似た傾向を示し ており、安政江戸地震の震度分布とも一致する。震源過程に関する 不確定性は残るが、太平洋プレート上面付近で発生する地震を想定
することによって、安政江戸地震の震度分布に見られる震度 $4 、 5$ の範囲が大きく広がる特徵が再現されるという結果を得た。この理 由として、震源位置がやや哚いために、相対的に震源特性よりも伝 播経路や地盤特性の影響を強く受けるためと考えられる。

ただし、本研究では、要素地震の震源位置と、推定地震の断層面 上の各小領域位置との差が、観測点との相対的位置関係から見て大 きい場合に生じる、伝播特性や震源放射特性の違いによる影響を無 視している。震源放射特性については、既往の観測的な研究[例えば Wald et al.(1988)181]より計测震度に強く影響する帯域では放射特 性が等方的となることから、放射特性の違いによる影響は大きくな いものと仮定して検討を進めた。

また、本研究では、震度と計測震度を直接比較して検討を行って いる。気象庁計測震度は震度 5 以下では多くの資料に基づいている が、震度 5 を超える高階震度については更なる経験が必要とされて いる。従って、推定した計測震度 6 以上の分布と、安政江戸地震の 震度 6 以上の分布が対応するとは限らない可能性がある。また、地 盤の非線形性を考虑していないなどの弱点もあり、より定量化に向 けて今後の課題としたい。

表 6 使用した要素地震の震源デー夕（気象庁、防災科技研による）

\begin{tabular}{|c|c|c|c|c|c|c|c|}
\hline & Date & Lon. & Lat. & Depth & M & strike & dip \\
\hline A & $1997 / 03 / 23$ & $140.1^{\circ}$ & $36.0^{\circ}$ & $70 \mathrm{~km}$ & 4.9 & $360^{\circ}$ & $68^{\circ}$ \\
\hline B & $1999 / 09 / 13$ & $140.160^{\circ}$ & $35.566^{\circ}$ & $77.1 \mathrm{~km}$ & 5.0 & $155^{\circ}$ & $37^{\circ}$ \\
\hline
\end{tabular}

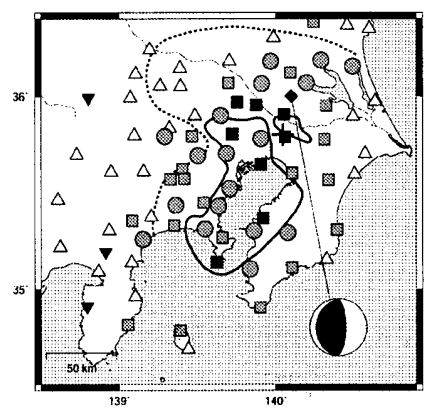

(a)要素地震 A の場合

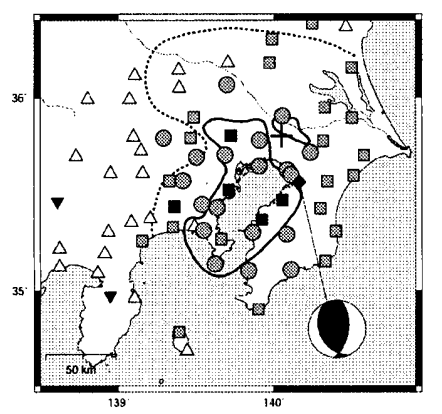

（b)要素地震 B の場合
図 11 異なる要素地震から計算される計測震度分布

\section{6. 浅発地震の検討}

震源深さが $30 \mathrm{~km}$ よりも浅い地震については、対象とする浅発地 震の観測記録は少なく、2 章及び 4 章で実施した検討を十分に行う ことができない。特に、 4 章と同様のパラメーター検討を行うため の要素地震とする地震が多くの地点で観測されていない。本章では、 要素地震の適合性に関する疑問はあるが、参考のために、この場合 も 1998 年 8 月 29 日に東京湾で発生したマグニチュード 5.1 の地震 を要素地震として 4 章と同様の検討を行った。

2 章の結果から $30 \mathrm{~km}$ より浅い場所で発生する地震では、 $30 \mathrm{~km}$ より深い場所で発生する地震よりも平均的な応力降下量が小さいと 予想される。従って、定量的にその効果を考虑に入れるため、図 2 において $30 \mathrm{~km}$ 以浅で発生した地震のうちマグニチュード 4 以上 (地震モ一メントが約 $10^{15} \mathrm{~N} \cdot \mathrm{m}$ 以上)の地震に対して、 $f_{0} \propto M_{0}^{-1 / 3}$ と いう関倸が成り立つと仮定して、Brune モデルを近似した場合の実 効応力を $14 \mathrm{MPa}(140 \mathrm{bar})$ と見積った。浅い地震に対する Brune モ デルの近似直線を図 2 に破線で示す。その值から、推定する地震と 
要素地震の実効応力の比 (0.54)を補正して合成を行う方法として、 横井・入倉(1991)19)に従い合成を行い、4 章と同様の震源パラメー ターを検討した。ただし、震源深さは図 12 に示すように、フィリピ ン海プレート上面付近での地震を想定し、北側ほど深くなるように 考えた。想定する断層面の走向と傾斜角は要素地震と同じを考えた。 結果のうち、マグニチュードは 7.1 の場合が最も良い結果となっ た。マグニチュードを 7.1 として、震源位置を変えた場合の結果を 図 13 に示す。震源を東京湾直下とした場合（左）は計測震度 6 の 範囲が広がりすぎている。また、安政江戸地震の震度分布で震度 5 となる範囲の北側で、計測震度が 4 になっている地点が多い。これ と比較すると、震源位置が千葉県と茨城県の県境付近の場合（右）

（震源深さ $30 \mathrm{~km}$ ）が、最も震度分布の対応が良い結果となった。 この場合の、全観測点での結果をまとめて図 14 に示す。このとき の震源パラメーターを表 7 に示す。推定した計測震度分布は安政江 戸地震の震度分布をよく再現している。しかし、広域で比較すると、 安政江戸地震の震度分布で震度 5 である千葉県の太平洋側や埼玉県 の一部で計測震度が 4 となる地点がある。また、安政江戸地震では、 広い範囲で震度 4 となるのに対して、東京都西部、神奈川県西部、 静岡県にかけて計測震度が 3 になる地点が多い。以上から、震源深 さを浅くした検討では、震度分布の広がりを十分に説明できず、震 源位置を深く考えた場合のほうが矛盾は少ない。

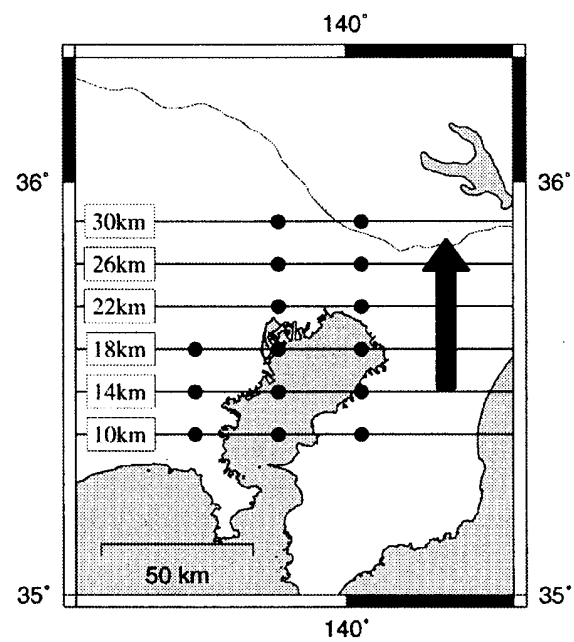

図 12 検討する震源深さ（6 章）

\section{7. 推定地震動の周期特性}

4 章で合成した地震動の周期特性に関して若干の検討を加える。 ただし、予測した地震動の波形は震源過程に大きく依存するため、 想定地震としての可能性のひとつとして捉えるべきである。ここで は、図 6 に示す東京都区部の 3 地点（震度 6 強となった足立、震度 6 弱となった新宿、震度 4 となった硬質地盤上の桧原）を取り上げ、 4 章で推定した地震（図 10 に対応）の加速度波形の例を図 15 に、 その加速度応答スペクトルを図 16 に示す。波形は地点によって、そ の地盤特性を反映して大きく異なっている。例えば足立の結果では 比較的周期の長いパルスが連続しており、新宿の結果ではきわめて 短周期が卓越している。加速度応答スペクトルは、足立の結果では、 0.7 秒程度に大きなピークを持っている。このようなピークは桧原 などの硬質地盤上では見られないため地盤特性と考えられる。1995 年兵庫県南部地震の大阪ガス茸合、神戸海洋気象台の記録、1993

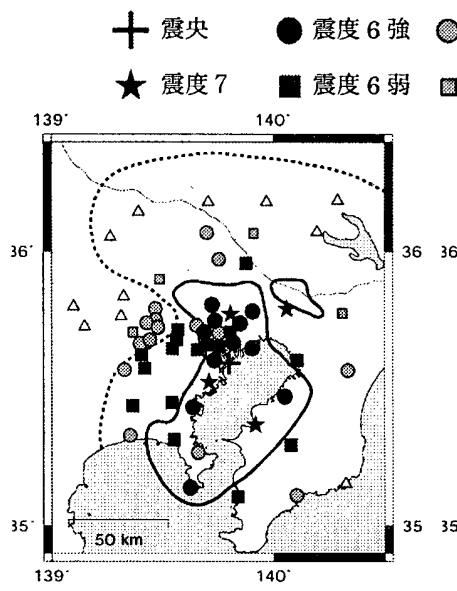

震央位置 $\left(35.60^{\circ} \mathrm{N}, 139.80^{\circ} \mathrm{E}\right)$ 潹さ $18 \mathrm{~km}$
震度 5 強 $\Delta$ 震度 4

震度 5 弱 $\mathbf{v}$ 震度 3

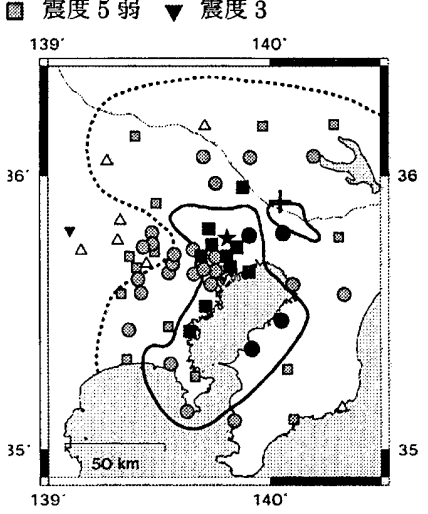

震央位置 $\left(35.91^{\circ} \mathrm{N}, 140.05^{\circ} \mathrm{E}\right)$ 深さ $30 \mathrm{~km}$
図 13 震源位置の違いによる霞度分布の比較（マグニチュード 7.1）

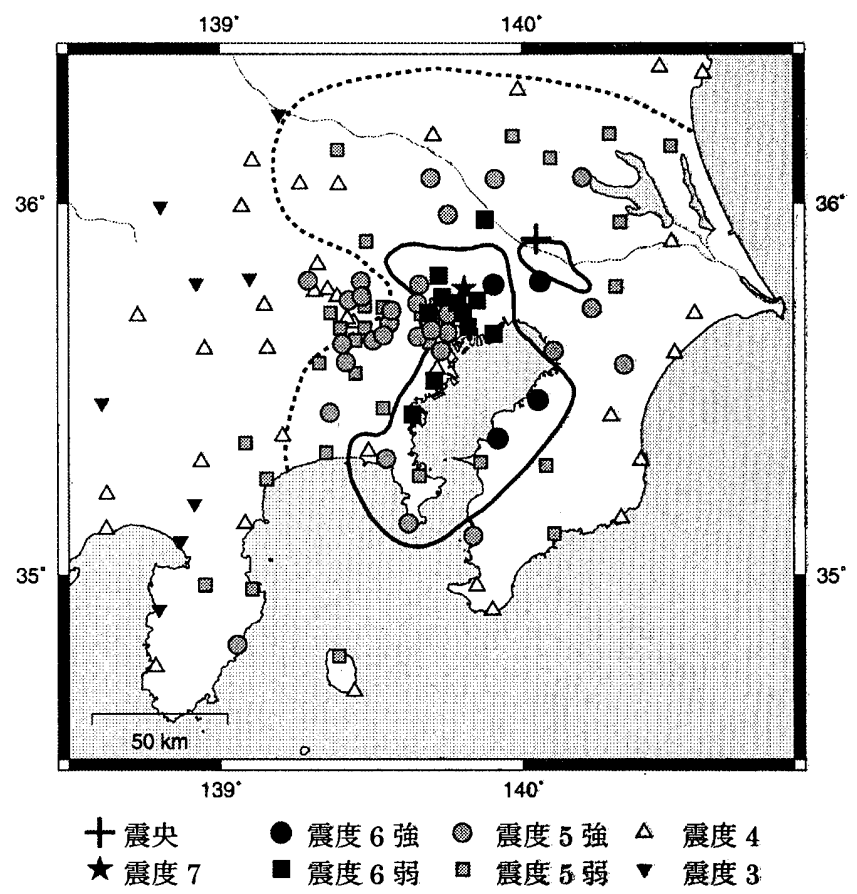

図 14 安政江戸地震の震度分布との比較 (6 章) （マグニチュード 7.1、震源媣さ $30 \mathrm{~km}$ )

表 7 結果(図 14)の震源パラメーター

\begin{tabular}{|c|c|}
\hline 走向 strike & $213^{\circ}$ \\
傾斜角 dip & $6^{\circ}$ \\
断層面積 $\mathrm{S}$ & $274.31 \mathrm{~km}^{2}$ \\
断層長 $\mathrm{L}$ & $11.72 \mathrm{~km}$ \\
断層幅 $\mathrm{W}$ & $5.86 \mathrm{~km}$ \\
分割数 $\mathrm{N}$ & 10 \\
立ち上がり時間 $\tau$ & $1.94 \mathrm{~s}$ \\
$\mathrm{~S}$ 波速度 $\mathrm{V}_{\mathrm{s}}$ & $3.5 \mathrm{~km} / \mathrm{s}$ \\
破壊伝播速度 $\mathrm{V}_{\mathrm{r}}$ & $2.52 \mathrm{~km} / \mathrm{s}$ \\
\hline
\end{tabular}

年釧路沖地震の釧路 JMA の記録による加速度応答スペクトルと算 純に比較しても、このピークが大きなレベルであることがわかる。 ただし、本解析では地盤の非線形性は考慮していない。

また、東京山の手を中心とする地点の応答スペクトルの多くは新 
宿の結果のように短周期側にピークを持ち、1 秒以上での応答は小 さく、1993 年釧路沖地震の釧路 JMA における記録の特徵と似てい る。釧路沖地震は震源涾さが $107 \mathrm{~km}$ であり、また、スラブ内地震 であったこと、さらに観測点周辺の、ごく表層の影響を受けていた ことなど、今回の検討地震と観測環境の類似から短周期地震動に類 似性が見られたものと考える。

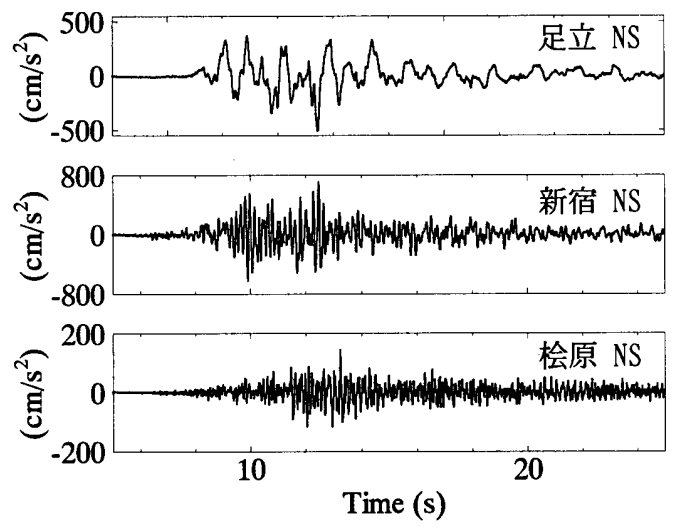

図 15 合成加速度波形の例
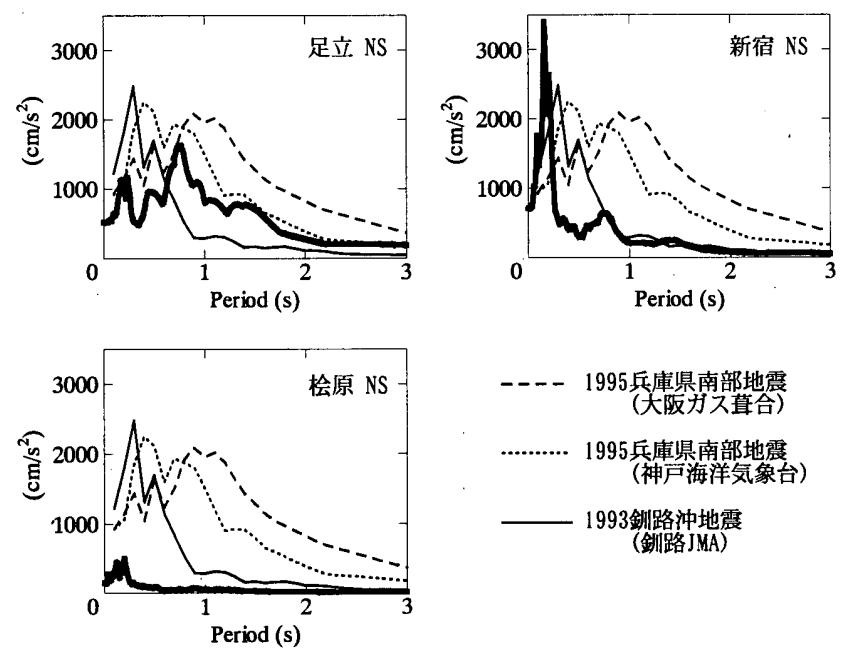

図 16 合成結果の加速度応答スペクトル $(\mathrm{h}=0.05)$

\section{8. まとめ}

首都圈地域で発生する地震に対して、哚さ $30 \mathrm{~km}$ 以上で発生する 地震では地震モーメントとコーナー周波数の間に従来の相似則が成 り立つことを確認し、その時 Brune モデルを当てはめた場合の実効 応力は約 $26 \mathrm{MPa}(260 \mathrm{bar})$ であった。この結果を基に、震源位置と マグニチュードをパラメーターとしてマグニチュード 7 クラスの地 震動推定を行った。その結果、震央位置が千葉、茨城県境付近 (北 緯 $35.80^{\circ}$ 、東経 $140.05^{\circ}$ )、震源の梁さが $68 \mathrm{~km}$ 、マグニチュー ドが 7.4 の場合に、推定した地震動による計測震度分布が、安政江 戸地震の震度分布を最も再現する結果となり、上記の震源パラメー ターが安政江戸地震の震源パラメーターを示す可能性が高いといえ る。このときの震央位置は宇佐美(1996)1により推定されている場所 よりやや北東であり、哚さは太平洋プレート上面付近 $(70 \mathrm{~km}$ 程度) に対応する。この結果は、震源深さに関する議論において、萩原 (1990)5)の指摘するやや深い地震に調和する。

過去に発生した地震の検討において、観測記録が残されていない
地震では、波形シミュレーション等による詳細な検討はできないた め、被害の記録あるいは震度分布に頼らざるを得ない。本研究の検 討手法のように震度を比較する場合には、震度階の粗い精度でしか 比較ができないが、比較する点を多く取ることによって、代表的な 震源パラメーターによる地震動強さの広がりを比較し、検討するこ とが可能である。地震観測網が整備され、多くの観測記録が得られ たことによって、このような検討が可能となった。本研究により、 従来の震度分布の経験的取り扱いから推定されていた安政江戸地震 の震源に、観測結果を用いたアプローチが可能であることが示され たと考える。今後、継続的な地震観測が行われ、多くの観測記録が 得られれば、更に詳細な検討も可能であり、歴史資料より推定され るのみであった地震像に計測量を組み込むことが可能と考えられる。

\section{謝辞}

宇佐美龍夫先生をはじめ歴史地震資料収集に携わられた多くの 方々に深甚の敬意を表します。また、東京都震度観測網、防災科学 技術研究所 K-NET、大阪ガス及び気象庁の波形データと防災科学 技術研究所 Freesia Project による広帯域地震波形を用いたメカ二 ズム解析結果を利用させて頂きました。関係各位に深く感謝致しま す。特に東京都震度観測網の波形データの利用に際して宮崎務博士 の御尽力に深く感謝致します。故南忠夫先生、小谷俊介先生、宇佐 美龍夫先生、都司嘉宣先生には多くの御教示を頂きました。また、 匿名査読者から想切かつ貴重なご意見をいただき改善に役立たせて 頂きました。記して御礼申し上げます。

\section{参考文献}

1) 宇佐美龍夫 : 新編日本被害地震総覧, 東京大学出版, 1996

2) 宇佐美龍夫 : 安政江戸地震の精密震度分布図, 1995

3) 宇佐美龍夫 : 新史料による安政江戸地震の調査, 地震研究所彙報, 第51号, 第 3-4冊, pp.209-230, 1976

4) 大竹政和 : 関東・東海地域のテクトニクスの統一モテルと南関東直下の地震の 発生メカニズム, 防災科学技術, No.41, pp.1-7, 1980

5) 萩原尊澧 : 江户-東京の直下地震, 古地震から探る, 地震ジャーナル, 第10号, pp.1-6, 1990

6) Irikura, $\mathrm{K}$ : Prediction of strong acceleration motions using empirical Green's function, Proc. 7th Japan Earthq. Eng. Symp., pp.151-156, 1986

7) 望月利男, 萑本孝久 : 安政江戸地震における関東地方の震度分布に関する研究, Proc. 7th Japan Earthq. Eng. Symp., pp.127-132, 1986

8) Aki, K : Scaling law of seismic spectrum, J. Geophys. Res., Vol.72, pp.1217-1231, 1967

9) Yoshimoto, K, H. Sato and M. Ohtake : Frequency dependent attenuation of $P$ and $S$ waves in the Kanto area, Japan, based on the coda normalization method, Geophys. J. Int., Vol.114, pp.165-174, 1993

10) Brune, J. N. : Tectnic stress and the spectra of seismic shear waves from earthquakes, J. Geophys. Res., Vol.75, pp.4997-5009, 1970

11) Kanamori, H. : The energy release in great earthquakes, J. Geophys. Res., Vol.82, pp.2981-2987, 1977

12) Kanamori, $H$. and $\mathrm{O}$. Anderson : Theoretical basis of some empirical relations in seismology, Bull. Seism. Soc. Am., Vol.65, pp.1073-1095, 1975

13) Sato, T. and T. Hirasawa : Body wave spectra from propagating shear cracks, J. Phys. Earth, Vol.21, pp.415-431, 1973

14) Geller, R. J. : Scaling relations for earthquake source parameters and magnitudes, Bull. Seism. Soc. Am., Vol.66, pp.1501-1523, 1976

15）宇津徳治 : 各種マグニチュード間の関係，地震研究所彙報，第57号，第3冊， pp.465-497, 1982

16) 堀 貞喜 : 1985年10月4日干葉茨城県境付近に発生した地震の発生メカ二ズムと その構造的意義について, 地震第2輯, 第39巻, pp.457-468, 1986

17) 気像庁監修 : 震度を知る, ぎょうせい, 1996

18) Wald, D. J., L. J. Burdick and P. G Somerville : Simulation of acceleration time histories close to large earthquake, Proc. of Earthq. Eng. and Soil Dynamic II Conference, ASCE, pp.430-444, 1988

19）横井俊明，入倉孝次郎 : 震源スペクトルのScaling則と経験的Green関数法，地震 第2輯, 第44巻, pp.109-122, 1991

（2000年10月 10 日原稿受理，2001年 4 月11日採用決定） 